\title{
First occurrence of Rosalia longicorn Rosalia alpina (Linnaeus, 1758) in the valley of the Drava River (Hungary)
}

\author{
JENÖ J. PURGER \\ Department of Ecology, Institute of Biology, Faculty of Sciences, \\ University of Pécs, H-7624Pécs, Ifjúság útja 6., Hungary, \\ E-mail: purger@gamma.ttk.pte.hu
}

Purger, J. J.: First occurrence of Rosalia longicorn Rosalia alpina (Linnaeus, 1758) in the valley of the Drava River (Hungary).

Abstract: One male of Rosalia longicorn Rosalia alpina (Linnaeus, 1758) was found on the shore of the OldDrava side arm near Barcs on the 1st July 2016. This was the first finding of this rare, Natura 2000 species in the area of the Drava valley which belongs to the Danube-Drava National Park.

Keywords: distribution, long-horn beetles, Natura 2000, saproxilic species, Somogy

\section{Introduction}

Rosalia longicorn Rosalia alpina (Linnaeus, 1758) is a saproxilic beetle species which is endangered and strictly protected through its range (CIZEK et al. 2009) and it is also listed among species of special interest for the European ecological network Natura 2000 (European Commission 1992). This species lives in the forests of the mountains and hilly regions in Hungary. It occurs in the beech zone in the North Hungarian Mountains (Északi-középhegység) and Transdanubian Mts. (Dunántúli-középhegység), Mecsek Mts, Transdanubian Hills (Dunántúli-dombság) as well as in the Villány Hills (HEGYESSY \& Merkl 2014, Gy. Dudás pers. comm.). This species was not registered during the previous studies of long-horn beetles along the Drava River (HORVATOVICH 1995, 1998). Rosalia longicorn was not found either on the Croatian side of the Drava River (KATUŠÍ et al. 2017).

\section{Material and methods}

The natural values in the Old-Drava, side arm of the Drava River near Barcs, Somogy County (XL89 - according 10×10 km UTM), belonging to Danube-Drava National Park were investigated between 2015 and 2017. During intensive field work, special attention was paid to revealing Natura 2000 species and forest habitats (91E0 - Alluvial forests 
with Alnus glutinosa and Fraxinus excelsior (Alno-Padion, Alnion incanae, Salicion albae) (SzMORAD 2014) and 91F0 - Riparian mixed forests of Quercus robur, Ulmus laevis and U. minor, Fraxinus excelsior or F. angustifolia, along the great rivers) (KIRÁLY \& SZMORAD 2014).

\section{Results and discussion}

During field work along the Old-Drava side arm one male specimen of Rosalia longicorn was found in the edge of the alluvial forest on 1st July 2016. This rare Natura 2000 species was recorded near Lóka-sarok locality (N45 58'5.07”, E17²1'40.31’), cca. 60 $\mathrm{m}$ to the northwest from the B733 border stone. Rosalia longicorn was observed on a leaf of dewberry (Rubus caesius L.) shrub, 30-40 cm above moist ground. Photographs were taken from $1 \mathrm{~m}$ distance without disturbing the animal (Fig. 1).

Rosalia longicorn has been considered as a montane species, associated with beech (Fagus sylvatica) in Central Europe, whereas in southern Europe this species has often been reported from lowlands, and its host spectrum is broader (CIZEK et al. 2009). According to HEGYESSY and MERKL (2014) it is a characteristic species of beech forests, though in Hungary it rarely occurs in other mixed forest communities with beech. Its larvae develop during several (2-4) years in dead trunks and their host plants can also be trees other than beech, e.g. hornbeam (Carpinus betulus), field maple (Acer campestre), sycamore (A. pseudoplatanus), Norway maple (A. platanoides), common ash (Fraxinus excelsior), narrow-leaved ash (F. angustifolia ssp. danubialis), wich elm (Ulmus glabra) and lime species (Tilia spp.) (HegYessy \& MERKL 2014). Adult male individuals of Rosalia longicorn emerge from the tree in June (one week earlier than females) and they are very active during hot summer days (HEGYESSY \& MERKL 2014). The mobility of this species and dispersal up to $1.6 \mathrm{~km}$ is reported by DRAG et al. (2011). The male individual of Rosalia longicorn observed in the Drava valley was more than $30 \mathrm{~km}$ distance from its previously known occurrences in Hungary (Fig. 2.) and Croatia (Katušić et al. 2017), therefore it probably could not come from these areas. CIzEK et al. (2009) suggest that Rosalia longicorn spreads into Central European lowland forests along large rivers, and that the spectra of hosts and habitats exploited are wider than generally thought. The forests in the area along the Drava River belonging to Danube-Drava National Park contain a lot of fallen trunks of various tree species which are potential hosts of Rosalia longicorn, therefore these habitats can be considered as suitable for their colonisation.

Acknowledgement: Mobility for the research was facilitated by Danube-Drava National Park Directorate (project: LIFE 13/Nat/HU000388 Life Old-Drava). 


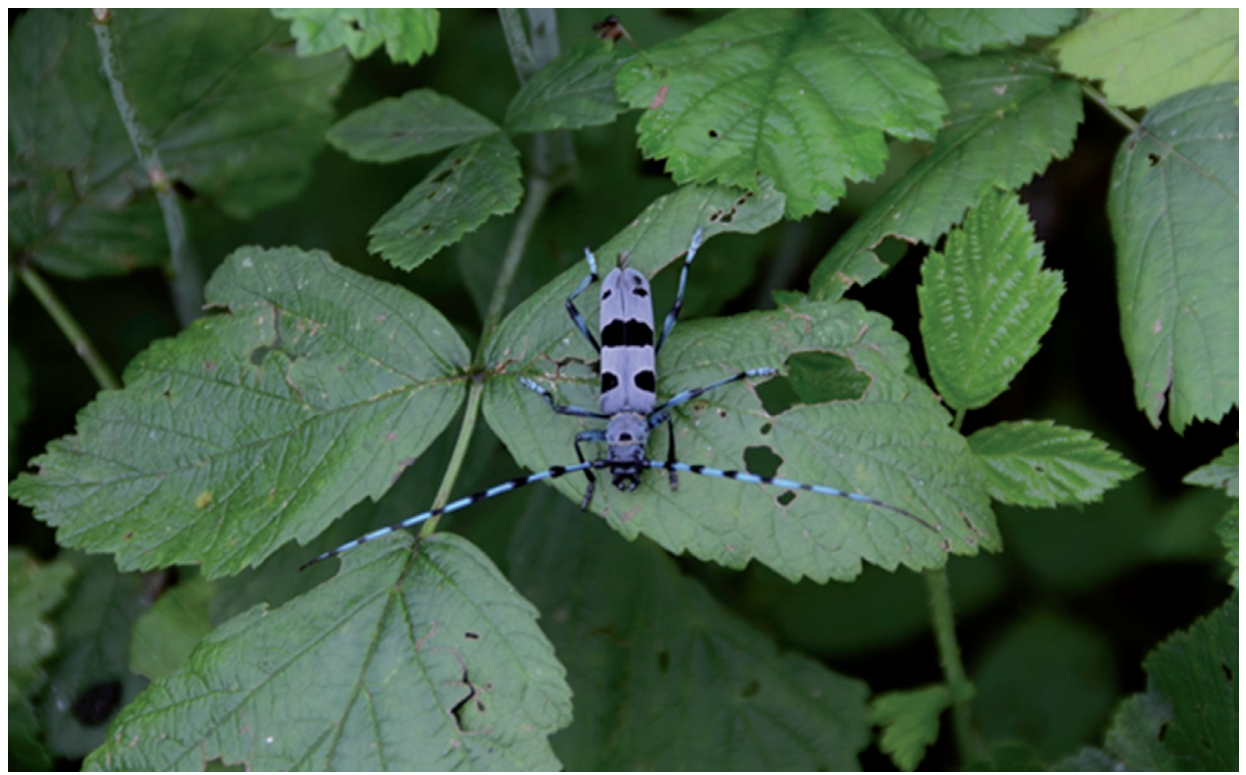

Fig. 1: A male Rosalia longicorn Rosalia alpina (Linnaeus, 1758) on the shore of the Old-Drava side arm near Barcs on 1st July 2016 (Photo J. J. PURGER)

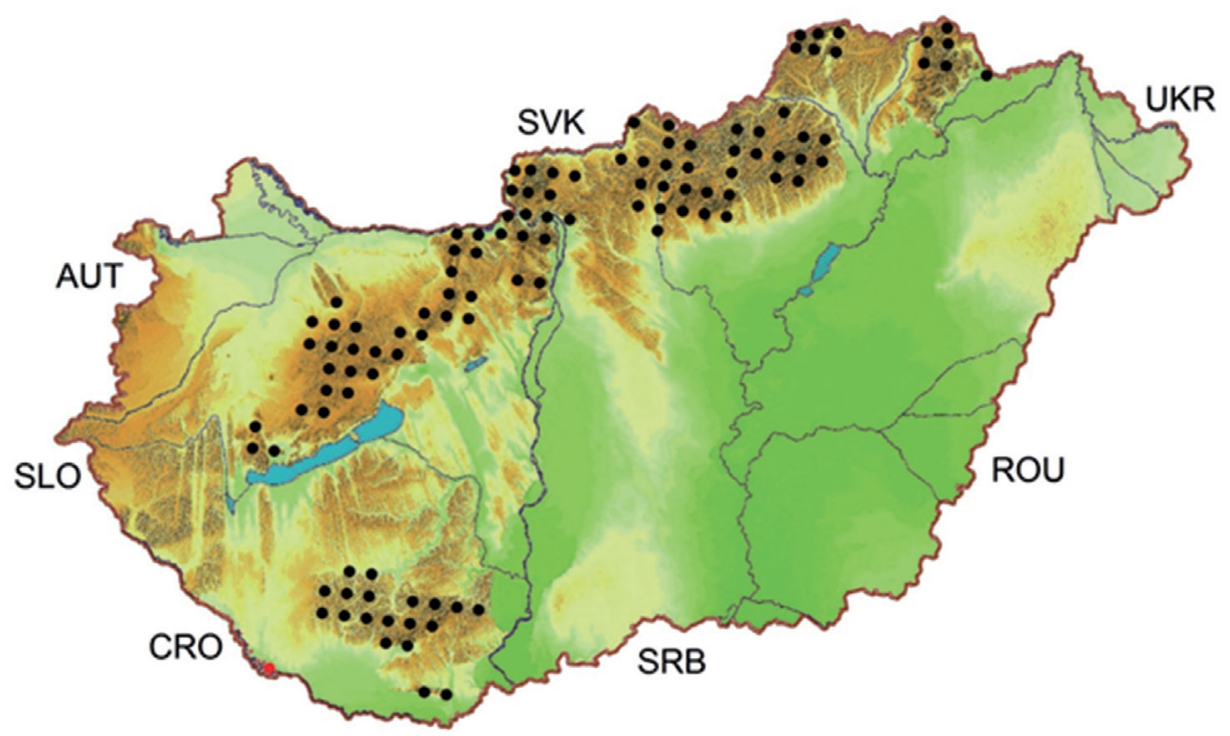

Fig. 2: Distribution map of Rosalia longicorn Rosalia alpina (Linnaeus, 1758) in Hungary (HEGYeSSY \& MERKL 2014), modified: the red circle indicates the first occurrence (UTM: XL89) in the Drava valley in the Danube-Drava National Park. 


\section{References}

Cizek, L., SchlaghamerskÝ, J., BoŘuckÝ, J., Hauck, D. \& Helešic, J. 2009: Range expansion of an endangered beetle: Alpine Longhorn Rosalia alpina (Coleoptera: Cerambycidae) spreads to the lowlands of Central Europe. - Entomologica Fennica 20: 200-206.

Drag, L., Hauck, D., Pokluda, P., Zimmermann, K. \& Cizek, L. 2011: Demography and Dispersal Ability of a Threatened Saproxylic Beetle: A Mark-Recapture Study of the Rosalia Longicorn (Rosalia alpina). PLoS ONE 6(6): e21345. doi:10.1371/journal.pone.0021345

European Commission 1992: Council Directive 92/43/EEC of 21 May 1992 on the conservation of natural habitats and of wild fauna and flora. http://ec.europa.eu/environment/ nature/legislation/habitatsdirective/ index_en.htm

Hegyessy, G. \& Merkl, O. 2014: Rosalia longicorn Rosalia alpina (Linnaeus, 1758). - Pp: 265-269. In: Haraszthy, L. (Ed.) Natura 2000 species and habitats in Hungary. Pro Vértes Közalapítvány, Csákvár. (in Hungarian)

Horvatovich, S. 1995: The Cerambycidae (Coleoptera) fauna of the Drava region (Hungary). - Studia Pannonica (A) Series Historico-Naturalis 8: 93-97. (in Hungarian)

Horvatovich, S. 1998: The Cerambycidae (Coleoptera) fauna of the Drava region (Hungary), II. - Studia Pannonica (A) Series Historico-Naturalis 9: 243-247. (in Hungarian)

Katuší́, L., Jelaska, S. D. \& Šerić Jelaska, L. 2017: Monitoring of saproxylic beetles in Croatia: following the path of the stag beetle. - In: Campanaro, A., Hardersen, S., Sabbatini Peverieri, G., Maria Carpaneto, G. (Eds) Monitoring of saproxylic beetles and other insects protected in the European Union. - Nature Conservation 19: 39-56. https://doi. org/10.3897/natureconservation.19.12683

KIRÁLY, G. \& SzMORAD, F. 2014: 91F0 Riparian mixed forests of Quercus robur, Ulmus laevis and U. minor, Fraxinus excelsior or F. angustifolia, along the great rivers. - Pp: 888-893. In: HaraszThy, L. (Ed) Natura 2000 species and habitats in Hungary. Pro Vértes Közalapítvány, Csákvár. (in Hungarian)

Szmorad, F. 2014: 91E0 Alluvial forests with Alnus glutinosa and Fraxinus excelsior (Alno-Padion, Alnion incanae, Salicion albae) - Pp: 881-887. In: HarASzTHy, L. (Ed) Natura 2000 species and habitats in Hungary. Pro Vértes Közalapítvány, Csákvár. (in Hungarian) 